\title{
Modelling the World Wool Market: A Hybrid Approach
}

\author{
George Verikios \\ Access Economics Pty Ltd, PO Box 6248, Kingston ACT 2604, Australia. \\ Email: George.Verikios@AccessEconomics.com.au; tel: 612 6273 1222; fax: 61262731223.
}

\begin{abstract}
We present a model of the world wool market that merges two modelling traditions: the partialequilibrium commodity-specific approach and the computable general-equilibrium approach. The model captures the multistage nature of the wool production system, and the heterogeneous nature of raw wool, processed wool and wool garments. It also captures the important wool producing and consuming regions of the world. We illustrate the utility of the model by estimating the effects of tariff barriers on wool products using partial- and general-equilibrium solutions. We find that either solution generates similar wool industry results, whereas the macroeconomic effects differ significantly with the partial-equilibrium estimates significantly overestimating the benefits of the tariff changes.
\end{abstract}

JEL codes: $\quad$ C68, D58, F11,Q10

Keywords: general equilibrium, multistage production, partial equilibrium, tariffs, wool products.

\section{Acknowledgements}

Parts of this work were undertaken during my PhD candidature at The University of Western Australia. As such, thanks are due to my PhD supervisor, Ken Clements, for helpful comments on this work. Parts of this work were also undertaken during the project Economic Aspects of Wool in Western Australia, jointly financed by the Australian Research Council and the Department of Agriculture Western Australia, and also conducted at The University of Western Australia. The views expressed in this paper are the author's and do not necessarily represent those of the financing institutions or Access Economics. 


\section{Introduction}

Scholars and policymakers interested in analysing economic aspects of the world wool market are faced with a particular challenge; there exists a dearth of models available for such a task. The dearth is a function of the challenges in modelling a market that is characterised by a number of special features. One, wool passes through an extreme form of multistage production before it is consumed by households in the form of wool garments, i.e., it is possible to identify at least four production stages at a broad level; primary production, spinning, weaving, garmentmaking. Two, the regional pattern of output and exports at the primary end of the world wool market strongly diverges from the pattern of production and exports at the different production stages. For instance, at the spinning (or yarn) and garment-making stages the use of wool is concentrated in Western European countries (particularly Italy and the United Kingdom) and the Far East (particularly China). At the retail stage Germany and France, as well as Italy and the United Kingdom, are important Western European consumers of wool, and Japan, as well as China, is an important Far East consumer of wool (TWC 2002). Here we address the needs of scholars and policymakers interested in analysing economic aspects of the world wool market, by developing a model that represents the special features.

The model explicitly captures the multistage nature of the production system through which wool passes, i.e., all the major stages of production from the sheep farm to wool garments. It also captures the heterogeneous nature of raw wool, by distinguishing fibre diameter and hauteur (length), and processed wool and wool garments, by representing the multistage woollen and worsted production systems that are part of the broader multistage wool production system. A further feature of the modelling framework is to represent all of the major raw wool, wool textile and wool garment producing and consuming regions of the world. Linking each of these regions via international trade in raw wool, wool textiles and wool garments, also captures linkages between wool industries in different regions.

However, the model goes further than representing just the world wool market in isolation, by embedding it within the broader economy. Thus, we take a hybrid approach by combining two long and rich modelling traditions. First, the partial-equilibrium commodity-specific approach. There are a limited number of commodity-specific models of wool. Recent examples include Mullen et al. (1989), Connolly (1992), Tulpule et al. (1992), Layman (1999) and Verikios (2004). Second, the computable-general-equilibrium approach. The only example of a wool CGE model (that we are aware of) is CIE (2002). The model presented here builds on previous work. The result is a model that represents the world wool market in detail, while at the same time the rest of the economy, or nonwool economy, is represented through six representative agents: nonwool producers, capital creators, households, exporters, governments and importers. Including the nonwool economy in the analytical framework allows us to capture the indirect effects of changes in the world wool market on the wool economy and the nonwool economy.

The usefulness of the model is demonstrated by way of an illustrative application to estimate the distortionary effects of wool tariff barriers in place from 1997 to 2005 . We do this under alternative model closures: partial and general equilibrium. The results demonstrate the advantages of modelling the world wool market within the wider economy, and thus provide a starting point for policy makers, trade negotiators and producers to understand the global, regional and sectoral implications of wool tariff barriers. Such estimates are unprecedented in two respects. One, to our knowledge, no previous estimates of the effects of wool tariff barriers on wool industries and regional producers exist. Two, the estimates are generated within a framework that captures the general interdependence between the wool and nonwool economies. 


\section{The nature of the world wool market}

Wool, cotton and man-made fibres account for around 98\% of world fibre use. ${ }^{1}$ Amongst these three fibres, man-made fibres hold the dominant position accounting for around $60 \%$ of world fibre use; cotton accounts for around 36\% and wool around 2\% (TWC 2004). Wool's small share of world fibre use belies the concentration of wool production, exporting, importing and processing, amongst a few but different countries/regions.

In terms of primary production, Australia is the world's largest wool producer accounting for one-quarter of world wool output; China and New Zealand are the next most important producers at $16 \%$ and $11 \%$ each (TWC 2004). In terms of apparel wool, Australia's importance is even greater with it supplying around half of such wool (AWIL 2006). Similarly, nearly twothirds of wool exports are supplied by three countries alone: Australia, 40\%; New Zealand, 19\%; the United Kingdom (UK), 5\% (TWC 2004). Wool imports are somewhat less concentrated: China is the dominant importer (27\%), ${ }^{2}$ followed by Italy (10\%), India and the UK (8\% each), and France and Germany (5\% each).

At the spinning (or yarn) and weaving (or fabric) production stages, the use of wool is concentrated in the Far East (mainly China) at 30\%, Western Europe (mainly Italy and the UK) at $21 \%$, and the Indian subcontinent (mainly India and Pakistan) at $14 \%$. At the garmentmanufacturing stage, the regional concentration is similar but Western Europe is less important (16\%) and the Indian subcontinent more important (15\%). The consumption of wool at the retail stage (in the form of apparel, carpets, etc.) is distributed differently again. Here, Western Europe (mainly UK, Italy and Germany) and the Far East (mainly China and Japan) are equally important at 26\% each, and North America (mainly the United States) less important at $13 \%$ (TWC 2004).

The above discussion has hinted at four broad stages of production through which apparel wool passes; the left-hand side of figure 1 summarises this structure. Although highly simplified, this structure captures the multistage nature of the wool production system. But the outputs of each of the four production stages can be further disaggregated to provide a more realistic structure of the wool production system that underlies the world wool market. Raw wool produced at stage 1 can be disaggregated into greasy, scoured, carbonised, carded and combed wool. Wool yarn produced at stage 2 can be divided into worsted and woollen yarn, and similarly for wool fabrics produced at stage 3 and wool garments produced at stage 4 .

\footnotetext{
${ }^{1}$ All data discussed in this section refers to quantities and either 2003 or 2004.

2 This includes Hong Kong and Macau.
} 


\section{Figure 1 A simple representation of apparel wool production stages}

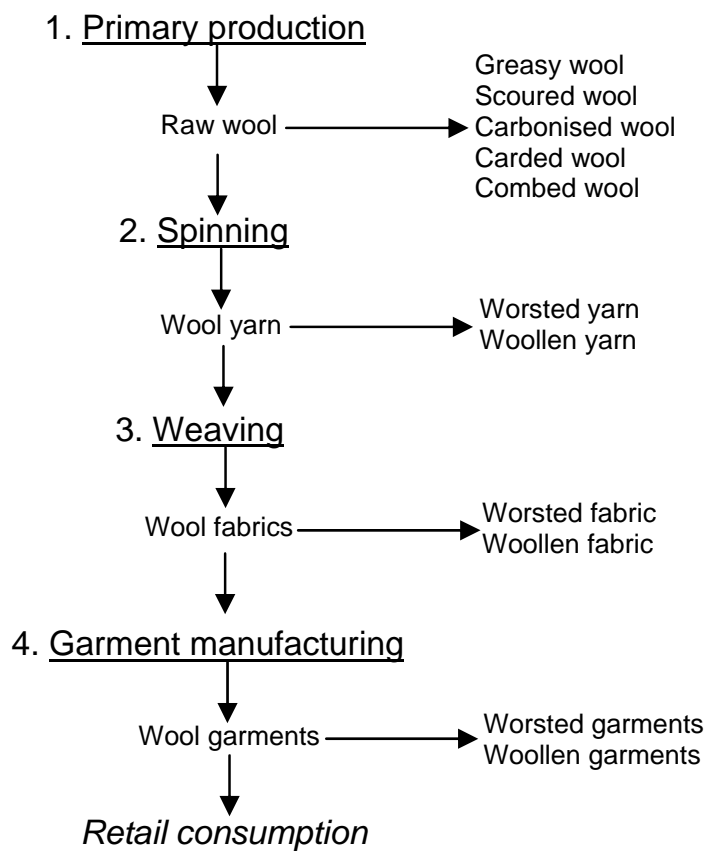

The wool production system begins with the production of greasy wool, which is removed from the sheep's back by shearing. Greasy wool is then washed (scoured) to remove extraneous matter, giving scoured wool. Some scoured wools are then carbonised to remove vegetable matter and then carded; other scoured wools bypass the carbonising process and are carded directly and then combed (the carding and combing processes prepare wool for the spinning process). At this point, wools now enter the spinning process where yarns are produced. In general, two types of yarns can be distinguished: worsted and woollen. Worsted yarns are produced from combed wools; woollen yarns are produced from carded wools. The distinction between worsted and woollen yarns is maintained through the weaving process where fabrics are produced and the manufacturing process where garments are produced.

Thus, there exist two sub-production systems within the broader apparel wool production system: the worsted system and the woollen system. ${ }^{3}$ The worsted and woollen sub-production systems give a flavour of the heterogeneous nature of the wool production system. The degree of heterogeneity can be further expanded. Raw wool (greasy, scoured, etc.) is commonly distinguished by hauteur (or length) and diameter. The properties, or qualities, of hauteur and diameter determine the type of processing and the range of products that can be made from a given batch of wool. Consequently, the qualities determine the relative price of different wools by reflecting the relative value of the end-use products that they enter. In general, finer wools fetch higher prices. In this work, these sub-qualities are used to represent a highly detailed wool production system.

\footnotetext{
${ }^{3}$ From the perspective of consumers, worsted fabrics are made with longer (yarn) fibres that produce a surface that is smooth to touch whereas woollen fabrics are made with shorter fibres that stand up from the surface and give the fabric a hairy touch (AWIL 2006).
} 


\section{Method}

The model developed here represents the synthesis of two modelling traditions: (i) the partial-equilibrium commodity-specific approach, and (ii) the computable-general-equilibrium (CGE) approach.

\subsection{The partial-equilibrium commodity-specific modelling approach}

Commodity-specific models have a long and rich history that began in the 1960s. They do not constitute a unique research stream but consist of an amalgam of work from agricultural economics, energy economics, mineral economics, marine economics, commodity futures and financial economics. These models feature varied methodologies, consisting of econometrics, mathematical programming, input-output analysis, and systems simulation theory and methods (Guvenen et al. 1991).

In aggregate, models of agricultural commodities vary widely but they all contain a number of common characteristics; inelastic demand, slow growth in total demand, competitive market structure, significant technological change, and the tendency of resources to become specific to the agricultural sector. For individual agricultural commodities the aggregate modelling approach is modified to account for additional characteristics that are unique to the commodity in question (Guvenen et al. 1991). The work presented here contains characteristics common to all agricultural models (inelastic demand, competitive market structure, sector-specific resources) and additional characteristics that are unique to wool (the multistage nature of the wool production system, heterogeneous treatment of wool products). Recent examples of commodityspecific models of wool include Mullen et al. (1989), Connolly (1992), Tulpule et al. (1992), Layman (1999) and Verikios (2004).

Mullen et al. (1989) construct an equilibrium displacement model of the world wool top industry, which uses wool and nonwool inputs to produce wool top. Wool inputs are distinguished between Australian and foreign supply. Connolly (1992) constructs an econometrically-estimated partial-equilibrium model of the world wool market and distinguishes between apparel and carpet wool. There are seven demand regions and five supply regions. The wool production system is depicted via three stages: raw wool production, textile production, and end-use products. Wool products from different regions are treated as differentiated products.

The model by Tulpule et al. (1992) is also econometrically estimated and partial equilibrium. It represents the wool production system via four production stages: wool top, yarn, fabric, and garments. Wool inputs to top production are distinguished between Australian and foreign supply. At each production stage, wool products are assumed to be differentiated on the basis of four categories of wool content: pure wool, wool rich, wool poor, and nonwool; there is no geographic differentiation of these products.

Layman (1999) represents a significant advance on the models already discussed. Similar to Mullen et al. (1989), it is an equilibrium displacement model, albeit a very large one. It depicts seven production stages: a sheep industry, scouring industries, carding/combing industries, yarn industries, fabric industries, wholesale garment industries and retail garment industries. It differentiates wool products by both quality (diameter, hauteur, worsted, woollen, woven, knitted, pure, blended, etc.) and place of production. Thus, 10 regions of the world are distinguished and international trade occurs in all wool products except retail garments. The degree of industry and commodity detail in Layman (1999) is unprecedented. Verikios (2004) uses the database of Layman (1999) to construct a model of the world wool market with a similar degree of industry/commodity detail. It departs from Layman (1999) by adjusting the benchmark data for discrepancies, using more flexible functional forms to represent demand and supply for all inputs and outputs, and updating all parameter values using a literature search and wool experts' advice. 


\subsection{The computable-general-equilibrium modelling approach}

The defining characteristic of CGE models is a comprehensive representation of the economy, i.e., as a complete system of interdependent components - industries, households, investors, governments, importers and exporters (Dixon et al. 1992). These can be single region models, e.g., Dixon et al. (1982), or multi-region models, e.g., Hertel (1997). It is not unheard of to incorporate the characteristics of commodity-specific models within a CGE framework, but it is uncommon. The most prominent examples of such a synthesis are the linking of input-output models of the energy sector with macroeconomic models (e.g., Hudson and Jorgenson 1974). A more recent example of such a synthesis is Trela and Whalley (1990), who construct a CGE model of textile and apparel markets with 14 specific textile and apparel categories and one composite other good, a single industry, and 37 regions trading regions. In terms of wool, the only example of a wool CGE model (that we are aware of) is CIE (2002), where GTAP, a multiregion CGE model (Hertel 1997), is disaggregated to distinguish raw wool, wool textile and wool garments sectors. The main drawback of such a model is the homogeneous representation of wool products.

In developing a synthesised wool model, we take a similar approach to Trela and Whalley (1990). Thus, we distinguish 54 individual wool products and two nonwool products (synthetic textiles and one composite other good). But our approach goes further, by distinguishing 42 individual wool industries and a separate composite other industries sector. The wool industries in each region are linked with the other industries sector through domestic factor markets, domestic and international markets for intermediate inputs, and domestic and international markets for household goods. This completes and complements the commodity-specific aspects of the model. This also constrains the behaviour of the wool economy in individual regions to assumptions about macroeconomic behaviour, such as a balance of trade constraint, and household and government consumption constraints. All of this is done at minimum computational cost, by representing nonwool industries and commodities as a single composite industry and commodity.

\section{Theoretical structure}

\subsection{Model overview}

The model applied here is comparative-static. It divides the world wool market into nine geographical regions representing all of the major raw wool, wool textile and wool garment producing and consuming regions of the world: France, Germany, Italy, UK, USA, Japan, China, Australia, and a Rest of World (ROW) region. Each region contains a single sheep industry, producing greasy wool and sheep meat. Greasy wool is distinguished by 3 diameter classes and 3 hauteur classes giving nine qualities of greasy wool. The nine qualities are tracked through five broad processing sectors ending with the production of 12 different types of wool garments that are consumed by a representative household.

The broad processing sectors in each region include scouring industries (of which there are nine), carbonising industries (three), worsted top industries (six - producing worsted tops, and noils), wool yarn industries (five), wool fabric industries (six), and wool garment industries (12). Besides sheep meat, two other nonwool commodities are distinguished: synthetic textiles and an 'other goods' composite. In total, there are 42 individual wool sectors and 54 individual commodities produced by these industries in each of the nine regions. ${ }^{4}$ Thus, the model distinguishes 378 separate wool industries and 486 separate wool commodities in total (figure 2).

\footnotetext{
${ }^{4}$ See the appendix for a complete listing of commodities and industries.
} 
The model also contains a comprehensive representation of the nonwool economy, including industries, households, investors, governments, importers and exporters.

\section{Figure 2 The industry and commodity structure of the model}

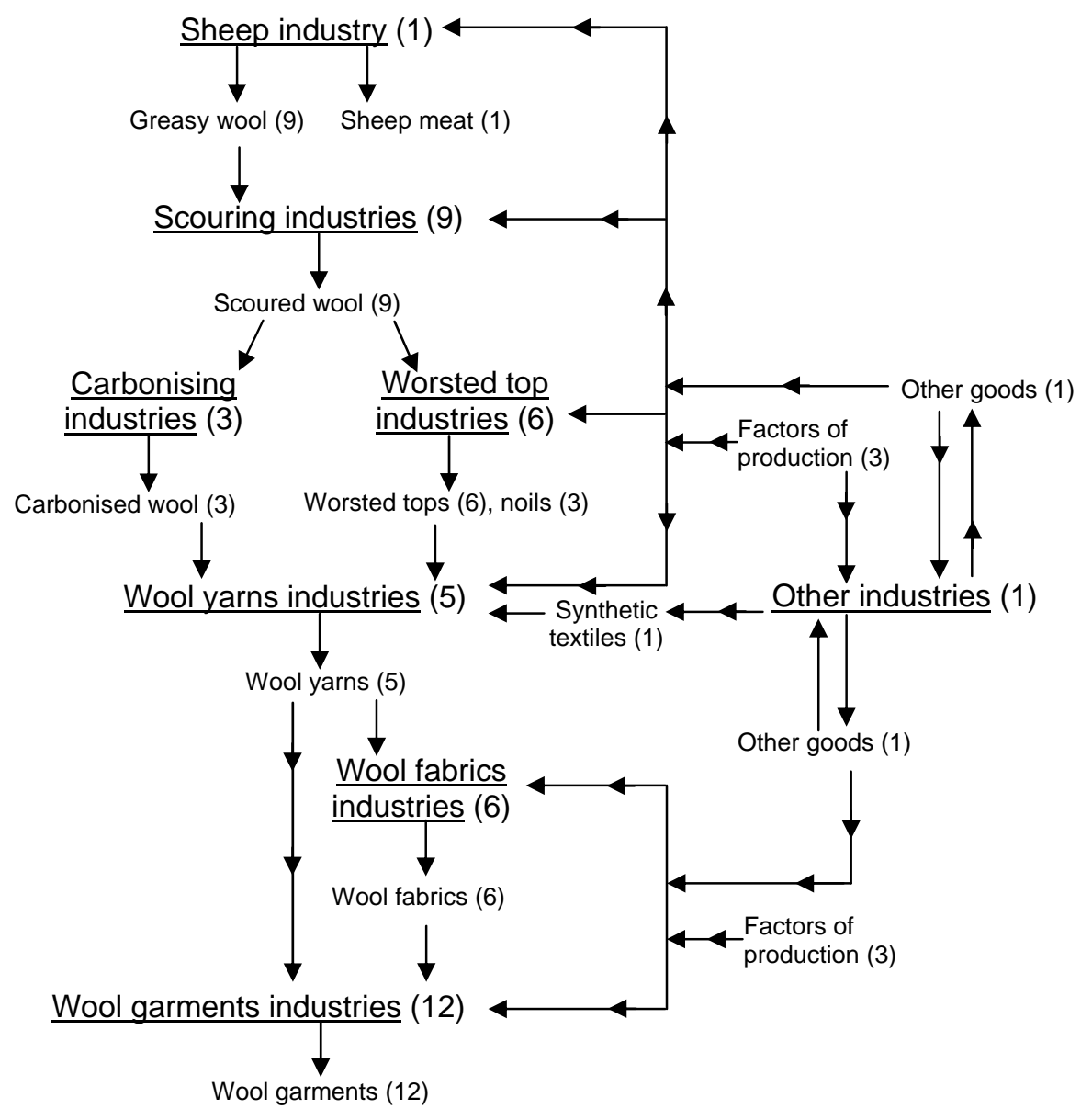

Note: Bracketed figures indicate the number of individual industries, commodities or factors of production in each region. Arrows indicate flows of inputs (commodities and factors of production) and outputs (commodities only) between industries.

\subsection{A linear equation system}

The model is represented by equations specifying behavioural and definitional relationships. There are $m$ such relationships involving a total of $p$ variables and these can be compactly written in matrix form as

$$
A \boldsymbol{v}=\mathbf{0},
$$

where $A$ is an $m \times p$ matrix of coefficients, $\boldsymbol{v}$ is a $p \times 1$ vector of percentage changes in model variables and $\mathbf{0}$ is the $p \times 1$ null vector. Of the $p$ variables, $e$ are exogenous (e.g., tariffs). The $e$ variables can be used to shock the model to simulate changes in the $(p-e)$ endogenous variables. Many of the functions underlying (1) are highly nonlinear. Writing the equation system like (1) allows us to avoid finding the explicit forms for the nonlinear functions and we can therefore write percentage changes (or changes) in the $(p-e)$ variables as linear functions of the percentage changes (or changes) in the $e$ variables. To do this, we rearrange (1) as

$$
A_{n} \boldsymbol{n}+A_{x} \boldsymbol{x}=\mathbf{0} \text {, }
$$


where $\boldsymbol{n}$ and $\boldsymbol{x}$ are vectors of percentage changes in endogenous and exogenous variables. $A_{n}$ and $A_{x}$ are matrices formed by selecting columns of $A$ corresponding to $\boldsymbol{n}$ and $\boldsymbol{x}$. If $A_{n}$ is square and nonsingular, we can compute percentage changes in the endogenous variables as

$$
\mathbf{n}=-A_{n}^{-1} A_{x} \boldsymbol{x} .
$$

Equations (1) represent the percentage-change forms of the nonlinear functions underlying the model; these forms are derived by total differentiation. Thus, (1) is an approximation based on marginal changes in the independent variables. So (3) only provides an approximate solution to the endogenous variables $\boldsymbol{n}$; for marginal changes in $\boldsymbol{x}$ the approximation is accurate but for discrete changes in $\boldsymbol{x}$ the approximation will be inaccurate.

The problem of accurately calculating $\boldsymbol{n}$ for large changes in $\boldsymbol{x}$ is equivalent to allowing the coefficients of the $A$ matrices to be nonconstant. The problem is solved by breaking the change in $\boldsymbol{x}$ into $i$ equal percentage changes. The multistep solution procedure requires that there are $(i-1)$ intermediate values of the underlying (levels) values of $\boldsymbol{n}$, i.e., $\boldsymbol{N}$. The intermediate values of $\boldsymbol{N}$ are obtained by successively updating the values of $\boldsymbol{N}$ after each of the $i$ steps is applied. Once the values of $\boldsymbol{N}$ are updated for any given step, the coefficients of the $\boldsymbol{A}$ matrices in (3) are recomputed before (3) is solved again. ${ }^{5}$ Below we present the most important behavioural equations in the model; the complete model equation system is documented in Verikios (2006a).

\subsection{Behavioural equations}

Representative firms are assumed to treat the three factors of production (agricultural land, labour and physical capital) as variable and take factor prices as given in minimising costs. Demands for primary factors are modelled using nested production functions consisting of two levels. At the top level, the $j(=1, \ldots, 43)$ firms in the $r(=1, . ., 9)$ regions decide on the (percentage change in) demand for the primary factor composite (i.e., an aggregate of land, labour and capital) $q f_{j r}^{F}$ using Leontief production technology:

$$
q f_{j r}^{F}=q f_{j r} ;
$$

where $q f_{j r}$ is (the percentage change in) the $(j, r)$-th industry's activity level (e.g., for the sheep industry this is an aggregate of greasy wool types and sheep meat).

At the second level, firms decide on their demand for the $i(=3)$ factors of production, $q f_{i j r}^{F}$. The underlying production technology applied in combining individual factors varies by type of industry: the sheep industry applies a CRESH (constant ratios of elasticities of substitution, homothetic) production function, whereas all other industries apply CES (constant elasticities of substitution) production functions:

$$
\begin{gathered}
q f_{i j r}^{F}=q f_{j r}^{F}-\sigma c r s h_{i r}^{F}\left(p f_{i j r}^{F}-p c r s h_{j r}^{F}\right), j=\text { Sheep } ; \\
q f_{i j r}^{F}=q f_{j r}^{F}-\sigma f_{j r}^{F}\left(p f_{i j r}^{F}-p f_{j r}^{F}\right), j=\text { Nonsheep } ;
\end{gathered}
$$

where the $\sigma \mathrm{s}$ are the relevant elasticities of factor substitution, $p f_{i j r}^{F}\left(p f_{j r}^{F}\right)$ is the individual (average) price of primary factors, and $p c r s h_{j r}^{F}$ is the CRESH equivalent of $p f_{j r}^{F}$. For the European regions, $\sigma c r s h_{i r}^{F}$ ranges over $0.2-0.35$ based on Salhofer (2000); for Japan, USA and

\footnotetext{
5 The model is implemented and solved using the multistep algorithms available in the GEMPACK economic modelling software (Harrison and Pearson 1996).
} 
Australia, $\sigma c r s h_{i r}^{F}$ ranges over 0.1-0.6 based on O'Donnell and Woodland (1995); for China and the ROW, $\sigma c r s h_{i r}^{F}$ ranges over $0.2-0.6$ based on guesstimates. The values of $\sigma f_{j r}^{F}$ for the wool processing industries are based mainly on Ramcharran (2001) and Jha et al. (1993), and range over $0.15-0.6$ for all regions. ${ }^{6}$

Firms are also assumed to able to vary the $k(=1, \ldots, 56)$ intermediate inputs (i.e., all goods) that they use in production, the prices of which they also take as given in minimising costs. In combining intermediate inputs, all firms are assumed to use three nested production functions. At level 1, all firms decide on their use of the intermediate input composite (e.g., for the scoured wool $[<20$ microns $(\mu \mathrm{m}),<56$ millimetres $(\mathrm{mm})]$ industry this is an aggregate of greasy wool [ $<20 \mu \mathrm{m},<56 \mathrm{~mm}]$ and 'other goods') $q f_{j r}^{I}$ using Leontief production technology;

$$
q f_{j r}^{I}=q f_{j r} .
$$

At level 2, firms decide on their use of the $k$ individual intermediate input composites (e.g., for the carbonised wool $[<20 \mu \mathrm{m},<56 \mathrm{~mm}]$ industry this is an aggregate of imported and domestically-produced scoured wool $[<20 \mu \mathrm{m},<56 \mathrm{~mm}]) q f_{k j r}^{I}$ using CES production technology,

$$
q f_{k j r}^{I}=q f_{j r}^{I}-\sigma f_{k r}^{I}\left(p f_{k j r}^{I}-p f_{j r}^{I}\right),
$$

where $\sigma f_{k r}^{I}$ is the CES for individual intermediate input composites, and $p f_{k j r}^{I}\left(p f_{j r}^{I}\right)$ is the individual (average) price of intermediate input composites. The values of $\sigma f_{k r}^{I}$ for carbonised wools, worsted tops, noils and synthetic textiles are taken from Beare and Meshios (1990) and Swan Consultants (1992) and range over 0.5-1.9, with most values exceeding 1. For all other commodities, $\sigma f_{k r}^{I}$ is set to 0.1 following Mullen et al. (1989).

At level 3, firms decide on their use of individual intermediate inputs (e.g., for the worsted blend yarn industry this will include synthetic textiles and different types of worsted tops) by source (domestic $q f d_{k j r}^{I}$ and imported $q f m_{k j r}^{I}$ ) also using CES production technology,

$$
\begin{aligned}
& q f d_{k j r}^{I}=q f_{k j r}^{I}-\sigma_{k r}^{T}\left(p f d_{k j r}^{I}-p f_{k j r}^{I}\right), \\
& q f m_{k j r}^{I}=q f_{k j r}^{I}-\sigma_{k r}^{T}\left(p f m_{k j r}^{I}-p f_{k j r}^{I}\right) ;
\end{aligned}
$$

where $\sigma_{k r}^{T}$ is the CES between any pair of individual intermediate inputs from different sources, and $p f d_{k j r}^{I}\left(p f m_{k j r}^{I}\right)$ is the domestic (imported) price of the $k$-th intermediate input. Based on advice from a wool industry expert (John Stanton, pers. comm., 2004), $\sigma_{k r}^{T}$ is set to 20 for raw wool (i.e., greasy, scoured, carbonised, top and noil), at 15 for wool textiles and 11.25 for wool garments. The values reflect the advice that while our commodity disaggregation is quite high implying high substitutability, more processed products take on different characteristics such that they are slightly differentiated across place of production.

All industries are modelled as multiproduct industries and are assumed to be price takers in choosing their output mix to maximise revenue. But the choice of output mix is only relevant for the multiproduct industries - the sheep industry and the worsted top industries. The actual outputs producible by each industry are strictly limited by the initial data due to the assumption of input-output separability, so that industries never alter the set of commodities for which they are (net) suppliers.

\footnotetext{
${ }^{6}$ Factor supplies by industry are determined by supply functions that assume labour and capital is perfectly mobile across all industries and agricultural land is very imperfectly mobile across industries.
} 
The sheep industry is assumed to determine its $c(=1, \ldots, 10)$ outputs (nine greasy wool types and sheep meat) using a CRETH (constant ratios of elasticities of transformation, homothetic) production possibilities frontier, whereas all other industries determine their $v$ $(=1, \ldots, 46)$ outputs using a CET (constant elasticities of transformation) production possibilities frontier;

$$
\begin{gathered}
q d_{c j r}=q f_{j r}-\theta c r t h_{c r}\left(p d_{c r}-p c r t h_{j r}\right), j=\text { Sheep }, \\
q d_{v j r}=q f_{j r}-\theta f_{j r}\left(p d_{v r}-p f_{j r}\right), j=\text { Nonsheep },
\end{gathered}
$$

where $q d_{w j r}$ is the $(j, r)$-th industry's supply of the $w$-th $(=c+v)$ domestically-produced commodity, $p d_{w r}$ is the common price of the $w$-th domestically-produced commodity, the $\theta$ s are the relevant elasticities of transformation, $p f_{j r}$ is the average price received by the firm for its outputs, and $p c r t h_{j r}$ is the CRESH equivalent of $p f_{j r}$. A market-clearing condition determines $p d_{w r}$. $\theta c r t h_{c r}$ is set at -2.83 for sheep meat and -1.38 for greasy wool based on Whipple and Menkhaus (1989). The values of $\theta f_{j r}$ (only relevant for worsted top industries) are set to zero following the advice of the same wool industry expert.

All firms are assumed to operate in perfectly competitive markets and so we impose a zeropure-profits condition that is expressed as equating revenues with costs;

$$
p f_{j r}+q f_{j r}=\sum_{i=1}^{3} S_{i j r}^{F}\left(p f_{i j r}^{F}+q f_{i j r}^{F}\right)+\sum_{k=1}^{56} S_{k j r}^{I}\left(p f_{k j r}^{I}+q f_{k j r}^{I}\right) .
$$

Equation (11) forces revenue for the firm $\left(p f_{j r}+q f_{j r}\right)$ to move with the sum of the costs of the $i$ factor inputs $\left(p f_{i j r}^{F}+q f_{i j r}^{F}\right)$ and $k$ intermediate inputs $\left(p f_{k j r}^{I}+q f_{k j r}^{I}\right)$, weighted by cost shares (the $S s)$. Equation (13) determines the $(j, r)$-th industry's activity level $\left(q f_{j r}\right)$.

Representative households in determine demand for their inputs to utility maximisation via a four-stage procedure. At level 1, households combine four broad composites - sheep meat, wool garments, synthetic textiles, and other goods - to maximise an implicit utility function. This gives a differential demand system written in terms of income and compensated price elasticities:

$$
q h_{i r}^{B}=\eta_{i r}^{B} q h_{r}+\sum_{j=1}^{4} \varepsilon_{i j r}^{B} p h_{j r}^{B}, i, j=1, \ldots, 4 .
$$

Equation (14) says that household demand for broad composite $i$ in region $r, q h_{i r}^{B}$, is subject to an income effect and a substitution effect. The income effect for the $(i, r)$-th broad composite is the product of the (normalised) income elasticity of demand for the (i,r)-th composite, $\eta_{i r}^{B}$, and demand for aggregate household consumption in the $r$-th region, $q h_{r}$. The substitution effect for the (i,r)-th broad composite is the sum of the compensated (own- and cross-) price elasticities of demand in region $r, \varepsilon_{i j r}^{B}$, multiplied by the price of the $(j, r)$-th broad composite, $p h_{j r}^{B}$. Most values of $\eta_{i r}^{B}$ are sourced from Dimaranan and McDougall (2002). After normalisation, values range across regions from $0.2-1.1$ for sheep meat, $0.7-0.9$ for wool garments and synthetic textiles, and $\geq 1$ for other goods. The values of $\varepsilon_{i j r}^{B}$ are calculated under the assumption of preference independence using the method described in Clements et al. (1995). The resulting values are around -0.2 for sheep meat, -0.4 wool garments and synthetic textiles, and close to zero for other goods. 
At level 2 households determine demand for the three wool garments subgroups (or blocks), $S_{1}, S_{2}, S_{3}$, that make up the wool garments broad composite - men's wool garments, women's wool garments, and knitted wool garments - applying Theil's (1980) differential approach to consumption theory. We assume block independence between these three subgroups so that utility derived from each block is assumed to be additive, giving the demand equations:

$$
q h_{i r}^{C}=\frac{\Theta H_{i r}^{C}}{W H_{i r}^{C}} q h_{j r}^{B}+\phi_{r} \frac{\Theta H_{i r}^{C}}{W H_{i r}^{C}}\left(p h_{i r}^{*^{C}}-p h_{j r}^{* B}\right), i=S_{1}, S_{2}, S_{3} ; j=\text { Wool garments. }
$$

Here, the demand for each of the $i\left(=S_{1}, S_{2}, S_{3}\right)$ wool garments subgroups, $q h_{i r}^{C}$, is a function of an expansion effect of the broad composite to which it belongs. The expansion effect is equal to $q h_{j r}^{B}$ multiplied by the ratio of the marginal share, $\Theta H_{i r}^{C}$, to the budget share, $W H_{i r}^{C}$, of each subgroup. Note that $\frac{\Theta H_{i r}^{C}}{W H_{i r}^{C}}$ is income elasticity for the (i,r)-th composite good. The substitution effect consists of the price elasticity of demand for the $i$-th subgroup (i.e., the income flexibility, $\phi_{r}$, multiplied by the income elasticity, ${ }^{7} \frac{\Theta H_{i r}^{C}}{W H_{i r}^{C}}$ ) multiplied by the change in the relative price of the $i$-th subgroup, $\left(p h_{i r}^{*^{*} C}-p h_{j r}^{* B}\right)$. Note that both prices are Frisch indices as they use marginal shares, rather than budget shares, as weights. Given that the ratio of the marginal budget share and the actual budget share represents the income elasticity for each good, $\left(\frac{\Theta H_{i r}}{W H_{i r}}\right)=\eta_{j r}^{B}$, we calculate the marginal budget shares as $\Theta H_{i r}=\eta_{j r}^{B} W H_{i r}$. The value of $\phi_{r}$ is taken from a number of studies supporting a value of -0.5 , all of which are discussed in Clements et al. (2006, p. 7).

At level 3, households determine demand for the $W G(=1, \ldots, 12)$ individual wool garments composites also using Theil's differential approach. The conditional demand equations are

$$
\begin{gathered}
q h_{i r}=\frac{\Theta H_{i r}}{W H_{i r}} \frac{W H_{j r}^{C}}{\Theta H_{j r}^{C}} q h_{j r}^{C}+\phi_{r} \frac{\Theta H_{i r}}{W H_{i r}}\left(p h_{i r}-p h_{j r}^{*^{C}}\right), \\
i \in S_{j} ; i=1, \ldots, 12 ; j=S_{1}, S_{2}, S_{3} .
\end{gathered}
$$

Demand for the $i$-th $(i=1, \ldots, 12)$ individual wool garment composite, $q h_{i r}$, is dependent upon two effects. The first of these is the change in demand for the subgroup to which it belongs, $q h_{j r}^{C}$ ( $j=S_{1}, S_{2}, S_{3}$ ), adjusted by the income elasticity of the $i$-th individual wool garment composite, $\frac{\Theta H_{i r}}{W H_{i r}}$, multiplied by the inverse of the income elasticity of the subgroup to which it belongs, $\frac{W H_{j r}^{C}}{\Theta H_{j r}^{C}}\left(j=S_{1}, S_{2}, S_{3}\right)$. The second effect is the change in the price of the $i$-th $(i=1, \ldots, 12)$ individual wool garments composite, $p h_{i r}$, relative to $p h_{j r}^{* C},\left(j=S_{1}, S_{2}, S_{3}\right)$, adjusted by the price elasticity of demand for the $i$-th $(i=1, \ldots, 12)$ good, i.e., $\phi_{r}\left(\frac{\Theta H_{i r}}{W H_{i r}}\right)$.

\footnotetext{
${ }^{7}$ This is the reciprocal of the income elasticity of the marginal utility of income.
} 
At the bottom level, households determine demand for the 15 individual goods from different sources using a CES utility function. The demand equations are

$$
\begin{aligned}
& q h d_{i r}=q h_{i r}+\sigma_{i r}^{T}\left(p h d_{i r}-p h_{i r}\right), \forall i, r, \\
& q h m_{i r}=q h_{i r}+\sigma_{i r}^{T}\left(p h m_{i r}-p h_{i r}\right), \forall i, r .
\end{aligned}
$$

Thus, demand for the $i$-th domestic (imported) individual good is a positive linear function of $q h_{i r}$ (the expansion effect) and the price of $i$-th domestic (imported) individual good $q h d_{i r}\left(q h m_{i r}\right)$ relative to $p h_{i r}$, adjusted by $\sigma_{i r}^{T}$ (the substitution effect). $p h_{i r}$ is an average of the price of the $i$-th domestic and imported good weighted by their respective budget shares.

All commodities are traded in the model and the decision on bilateral import demands is made by a representative importer who minimises the total cost of the $w$ imported goods from the $s(=1, \ldots, 9)$ sources subject to CES production technology:

$$
x_{w s r}^{X}=x_{w r}^{M}-\sigma_{w r}^{T}\left(p_{w s r}^{X}-p_{w r}^{M}\right),
$$

where $x_{w s r}^{X}$ is exports of good $w$ from region $s$ to region $r$ (e.g., exports of worsted blend woven fabric from Italy to the USA), $x_{w r}^{M}$ is composite imports of good $w$ by region $r$ (e.g., total imports of wholesale men's worsted blend woven garments by Japan), and $p_{w s r}^{M}\left(p_{w r}^{M}\right)$ is the price of $x_{w s r}^{X}\left(x_{w r}^{M}\right)$. A market-clearing condition determines $p_{w r}^{M}$.

The model contains $m$ equations and $p$ variables where $m<p$, so to close the model $e(=p-$ $m$ ) variables must be set as exogenous. The exogenous variables are chosen so as to simulate a long-run environment (table 1); this represents an adjustment period of around five to ten years between initial and new equilibriums. For the purposes of comparison, we also develop a partialequilibrium closure whereby various general equilibrium conditions are made redundant via the addition of endogenous shift terms. ${ }^{8}$ The main feature of the closure is the assumption of fixed prices of all primary factors, and industries that would not be explicitly modelled in a partialequilibrium model of the world wool market: the other industries composite. ${ }^{9}$ We also fix government and investment demands as these would also not normally be determinable in a partial-equilibrium model of the world wool market. Household consumption is determined making it a fixed share of household income via a fixed average propensity to consume.

\footnotetext{
8 This is another advantage of using linear approximations to represent the model.

9 Our representation of 'partial equilibrium' is one interpretation of this concept; the literature provides little guidance on the essential characteristics of a partial equilibrium. Hence, our interpretation is probably one of many that could be imagined. See Whalley (1975) for a discussion of this issue.
} 
Table 1 Exogenous variables in different model closures

\begin{tabular}{ll}
\hline \hline & General equilibrium \\
\cline { 2 - 2 } $\begin{array}{l}\text { Regional land usage } \\
\text { Regional labour usage }\end{array}$ & All indirect tax rates \\
Region-wide rate of return on capital & Ratio of government deficit to GDP \\
All technical change variables & Regional depreciation rate \\
(Change in) the demand for stocks by industry & Ratio of the trade balance to GDPa \\
& Global consumer price index \\
All factor prices & Partial equilibrium \\
All technical change variables & All direct and indirect tax rates \\
(Change in) the demand for stocks by industry & Regional depreciation rate \\
Price of other industries & Real investment expenditure \\
Household savings rates & Real government expenditure \\
\hline \hline
\end{tabular}

a In general equilibrium, the ratio of the trade balance to GDP is held fixed in all but one region.

\subsection{Numerical structure}

Here we refer briefly to the model database and its construction; a complete description of the model calibration is contained in Verikios (2006b).

In constructing the model database we disaggregate a widely-used and well-known database of the world economy, GTAP, that is specified in \$US for 1997 (Dimaranan and McDougall 2002). The database is comprehensive in its representation of the world economy. In disaggregating we apply data from Layman (1999), adjusted for discrepancies, as supplied by DAWA (2003), on the structure of individual wool commodities and industries in each of the more aggregated GTAP commodities and industries. This procedure gives a highly disaggregated wool commodities and industries structure while providing a highly aggregated representation of nonwool commodities and industries.

Table 2 presents the input-output shares, for the world as a whole, by broad inputs and industry. The most obvious feature of the aggregated input-output tables are their diagonal nature for the wool processing industries, reflecting a linear hierarchy where outputs from downstream processing industries are not used as inputs by upstream processing industries. In contrast, nonwool industries use each other's outputs as intermediate inputs. Factor usage in the five wool processing stages follow the same pattern as nonwool intermediate input usage, rising to around one-third of total costs from an initial share of around 8 per cent. This pattern is intuitive given that we expect value added, as a share total costs, to increase as we move from the production of slightly transformed goods, such as scoured wool, to more highly transformed goods, such as garments (see AWIL 2005, pp. 45-6). 
Table 2 Model input-output shares, World

\begin{tabular}{|c|c|c|c|c|c|c|c|c|}
\hline \multirow{2}{*}{$\begin{array}{l}\text { BROAD } \\
\text { INPUTS }\end{array}$} & \multicolumn{8}{|c|}{ 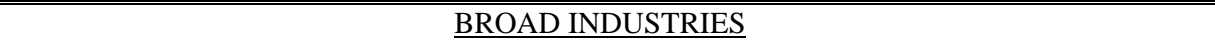 } \\
\hline & Sheep & $\begin{array}{c}\text { Scoured } \\
\text { wool }\end{array}$ & $\begin{array}{c}\text { Carbon } \\
\text { wool }\end{array}$ & $\begin{array}{c}\text { Worsted } \\
\text { tops }\end{array}$ & $\begin{array}{l}\text { Wool } \\
\text { yarns }\end{array}$ & $\begin{array}{l}\text { Wool } \\
\text { fabrics }\end{array}$ & $\begin{array}{c}\text { Wool } \\
\text { garments }\end{array}$ & $\begin{array}{c}\text { Other } \\
\text { industries }\end{array}$ \\
\hline Sheep meat & 0 & 0 & 0 & 0 & 0 & 0 & 0 & 0.1 \\
\hline Greasy wool & 0 & 90.1 & 0 & 0 & 0 & 0 & 0 & 0 \\
\hline Scoured wool & 0 & 0 & 83.9 & 75.0 & 0 & 0 & 0 & 0 \\
\hline Carbon wool & 0 & 0 & 0 & 0 & 26.8 & 0 & 0 & 0 \\
\hline Worsted tops & 0 & 0 & 0 & 0 & 14.7 & 0 & 0 & 0 \\
\hline Noils & 0 & 0 & 0 & 0 & 12.6 & 0 & 0 & 0 \\
\hline Wool yarns & 0 & 0 & 0 & 0 & 0 & 4.3 & 2.6 & 0 \\
\hline Wool fabrics & 0 & 0 & 0 & 0 & 0 & 0 & 20.8 & 0 \\
\hline Wool garms & 0 & 0 & 0 & 0 & 0 & 0 & 0 & 0.1 \\
\hline Synth textiles & 0 & 0 & 0 & 0 & 2.5 & 0 & 0 & 0.6 \\
\hline Other goods & 55.0 & 2.2 & 4.3 & 8.2 & 19.5 & 28.0 & 43.7 & 49.4 \\
\hline Value added & 45.0 & 7.7 & 11.8 & 16.8 & 23.9 & 27.8 & 33.0 & 49.9 \\
\hline TOTAL & 100.0 & 100.0 & 100.0 & 100.0 & 100.0 & 100.0 & 100.0 & 100.0 \\
\hline
\end{tabular}

\section{The nature of wool tariff barriers}

In section 6 we apply the movement in wool tariff barriers between 1997 and 2005 as an illustration of the model's utility; here we discuss the nature of wool tariffs. Import duties on wool products for 1997 are taken from TWC (2003) and applied to the model database; table 3 presents average import tariffs in the model database after applying the wool tariff data. We note that the global average tariff for all goods is $4.9 \%$. China has the highest overall import tariffs at around 13\%. Taxes on imports of wool products are much higher than for nonwool products for all regions; the highest tariff averages for imports of wool products are for the USA (48\%), China (28\%), Australia and the ROW (Rest of World) (32\%). Globally, import tariffs are lower for raw wool commodities (i.e., greasy, scoured and carbonised wools, worsted tops, and noils) compared to wool textiles (i.e., yarns and fabrics) and wool garments; for instance, the average tariff rate on greasy wool (5.8\%) is only around one-fifth of the rate on wool garments (28.5\%).

Table 3 Average import tax rates in model database representing 1997 wool tariff barriers (per cent)

\begin{tabular}{|c|c|c|c|c|c|c|c|c|c|c|}
\hline & France & Germ & Italy & UK & USA & Japan & China & Aust & ROW & World \\
\hline & \multicolumn{10}{|c|}{ WOOL PRODUCTS } \\
\hline Greasy wool & 0 & 0 & 0 & 0 & 20.4 & 0 & 9.0 & 0 & 11.0 & 5.8 \\
\hline Scoured wool & 0 & 0 & 0 & 0 & 20.4 & 0 & 9.0 & 0 & 11.0 & 4.9 \\
\hline Carbon wool & 1.9 & 1.6 & 2.0 & 1.2 & 11.8 & 0 & 10.0 & 0 & 21.0 & 2.3 \\
\hline Worsted tops & 1.9 & 1.6 & 1.4 & 0.9 & 11.8 & 0 & 10.0 & 0 & 21.0 & 1.9 \\
\hline Noils & 1.8 & 1.2 & 1.8 & 1.5 & 11.8 & 0 & 10.0 & 0 & 21.0 & 2.8 \\
\hline Wool yarns & 0.5 & 1.0 & 0.7 & 0.5 & 8.1 & 3.2 & 20.0 & 5.0 & 30.0 & 16.0 \\
\hline Wool fabrics & 0.3 & 0.4 & 1.6 & 0.8 & 68.1 & 0 & 35.0 & 0 & 34.5 & 25.4 \\
\hline Wool garms & 7.7 & 8.5 & 11.4 & 8.1 & 48.5 & 12.4 & 45.0 & 34.0 & 32.5 & 28.5 \\
\hline \multirow[t]{2}{*}{ Average } & 5.5 & 5.5 & 2.2 & 7.2 & 48.0 & 10.1 & 27.9 & 32.1 & 32.0 & 24.2 \\
\hline & \multicolumn{10}{|c|}{ NONWOOL PRODUCTS } \\
\hline Sheep meat & 5.5 & 13.3 & 7.0 & 18.6 & 1.1 & 149.1 & 2.1 & 0.2 & 20.4 & 16.4 \\
\hline Synth textiles & 4.3 & 5.3 & 5.0 & 5.3 & 8.8 & 8.1 & 25.0 & 13.9 & 10.1 & 9.7 \\
\hline Other goods & 1.4 & 1.7 & 1.4 & 2.1 & 2.3 & 6.9 & 13.0 & 3.5 & 5.9 & 4.7 \\
\hline \multirow[t]{2}{*}{ Average } & 1.4 & 1.8 & 1.4 & 2.2 & 2.4 & 6.9 & 13.3 & 3.7 & 6.0 & 4.8 \\
\hline & \multicolumn{10}{|c|}{ ALL PRODUCTS } \\
\hline Average & 1.5 & 1.8 & 1.5 & 2.2 & 2.8 & 6.9 & 13.4 & 3.8 & 6.1 & 4.9 \\
\hline
\end{tabular}


Table 4 presents the movement (percentage change) in wool tariffs from 1997 to 2005. These changes are based on 2005 wool tariffs sourced from TWC (2006) that have been mapped to the model database in the same way as 1997 wool tariffs. We can see that, overall, there has been a significant reduction in global wool tariff barriers of $40 \%$ over this period.

Table 4 Percentage change in average import tax rates, 1997-2005

\begin{tabular}{|c|c|c|c|c|c|c|c|c|c|c|}
\hline & France & Germ & Italy & UK & USA & Japan & China & Aust & ROW & World \\
\hline & \multicolumn{10}{|c|}{ WOOL PRODUCTS } \\
\hline Greasy wools & 0.0 & 0.0 & 0.0 & 0.0 & -8.3 & 0.0 & 116.7 & 0.0 & -89.4 & 22.5 \\
\hline Scourd wools & 0.0 & 0.0 & 0.0 & 0.0 & -8.3 & 0.0 & 116.7 & 0.0 & -89.4 & -36.1 \\
\hline Carbon wools & 0.0 & 0.0 & 0.0 & 0.0 & -41.5 & 0.0 & 105.0 & 0.0 & -82.5 & 2.7 \\
\hline Worsted tops & 0.0 & 0.0 & 0.0 & 0.0 & -41.5 & 0.0 & 105.0 & 0.0 & -82.5 & -14.2 \\
\hline Noils & 0.0 & 0.0 & 0.0 & 0.0 & -41.5 & 0.0 & 105.0 & 0.0 & -82.5 & -19.2 \\
\hline Wool yarns & 0.0 & 0.0 & 0.0 & 0.0 & -25.9 & -15.6 & -75.0 & 0.0 & -66.4 & -65.8 \\
\hline Wool fabrics & -34.7 & -34.7 & -34.7 & -34.7 & -63.3 & 0.0 & -71.4 & 0.0 & -57.5 & -60.3 \\
\hline Wool garms & -11.0 & -11.0 & -10.9 & -11.1 & -48.7 & -14.3 & -64.9 & -48.5 & -25.4 & -35.9 \\
\hline \multirow[t]{2}{*}{ Average } & -10.9 & -10.8 & -9.3 & -11.2 & -49.0 & -14.4 & -56.2 & -48.4 & -37.2 & -40.4 \\
\hline & \multicolumn{10}{|c|}{ ALL PRODUCTS } \\
\hline Average & -0.4 & -0.4 & -0.2 & -0.3 & -8.0 & -0.2 & -1.1 & -2.0 & -1.0 & -1.5 \\
\hline
\end{tabular}

On a broad commodity basis, the largest reductions have been in wool textiles (yarns, $66 \%$; fabrics, $-60 \%$ ); nevertheless, scoured wool and wool garments (-36\%) have also experienced large, but smaller, reductions. Note also that the reductions in wool tariff barriers for the period 1997-2005 have contributed to a reduction in the global tariff average on all goods of $1.5 \%$. Thus, despite wool commodities representing a small share of world trade, they have still made a small but observable contribution to overall tariff reductions during the period.

We observe a $22 \%$ increase in global average tariffs on greasy wools and a $3 \%$ increase on carbonised wools. The increases are due to a doubling of the tariffs we apply for raw wool imported by China. This reflects a doubling of the out-of-quota tariff, from $15 \%$ to $38 \%$, while the in-quota tariff has fallen: from 3\% to $1 \%$ for greasy wools and from $5 \%$ to $3 \%$ for wool top. Based on assessments by Read (2004) and van Rooyen (2006), it seems reasonable to assume that the out-of-quota tariff does not often apply. Consequently, we assume in our simulations for the 1997-2005 period that the 1997 tariffs on raw wool applied by China remain unchanged. ${ }^{10}$

Four regions have enormously reduced tariff barriers over the period as reflected by average wool tariffs; the USA (-49\%), China (-56\%), Australia (-48\%) and the ROW region ($37 \%)$. Much smaller reductions in average wool tariffs, in the order of $10 \%$, have also occurred in all other regions. We note that the composite ROW region shows some of the largest individual reductions in wool tariffs, particularly on raw wool (80-90\%). Given the size of these changes, it would be ideal for this region to be more disaggregated into the developing regions that have significantly reduced wool tariffs over this period. ${ }^{11}$ Unfortunately, our source data for wool commodities, industries and regions do not allow for a further disaggregation. Despite this constraint, this work represents a significant advancement when placed in the context of the absence of previous work in this area.

\footnotetext{
10 The model database also captures the distortions of the Agreement on Textiles and Clothing (ATC) by including export tax equivalents of ATC quotas in place at 1997. These distortions are also left untouched in the simulations.

11 Tariff data from TWC (2006) indicates that almost all of the reduction in ROW wool tariffs is due to reductions in India.
} 


\section{Simulation results}

We demonstrate the contribution of our hybrid approach by applying the changes in wool tariffs between 1997 and 2005 (summarised in table 4) and generating solutions using the partialand general-equilibrium closures described in section 4.3.

\subsection{Industry effects}

In presenting industry and commodity results we aggregate the 56 commodities and 43 industries to 11 broad commodity and 8 broad industry classes in order to keep the discussion of the results manageable. In partial equilibrium, the response of a given industry's output to the tariff changes will be largely determined by the interaction of two forces. One, the degree to which the prices of competing imports fall [panel (a), table 5]. Two, the degree to which the tariff barriers it faces in export markets fall [panel (b)].

Table 5 Changes in import tariffs and export barriers due to changes in tariff barriers, 1997-2005 (percentage change)

\begin{tabular}{|c|c|c|c|c|c|c|c|c|c|}
\hline & France & Germ & Italy & UK & USA & Japan & China & Aust & ROW \\
\hline & \multicolumn{9}{|c|}{ (a) Import tax rates } \\
\hline Greasy wools & 0.0 & 0.0 & 0.0 & 0.0 & -8.3 & 0.0 & 0.0 & 0.0 & -89.4 \\
\hline Scoured wools & 0.0 & 0.0 & 0.0 & 0.0 & -8.3 & 0.0 & 0.0 & 0.0 & -89.4 \\
\hline Carbon wools & 0.0 & 0.0 & 0.0 & 0.0 & -41.5 & 0.0 & 0.0 & 0.0 & -82.5 \\
\hline Worsted tops & 0.0 & 0.0 & 0.0 & 0.0 & -41.5 & 0.0 & 0.0 & 0.0 & -82.5 \\
\hline Noils & 0.0 & 0.0 & 0.0 & 0.0 & -41.5 & 0.0 & 0.0 & 0.0 & -82.5 \\
\hline Wool yarns & 0.0 & 0.0 & 0.0 & 0.0 & -25.9 & -15.6 & -75.0 & 0.0 & -66.4 \\
\hline Wool fabrics & -34.7 & -34.7 & -34.7 & -34.7 & -63.3 & 0.0 & -71.4 & 0.0 & -57.5 \\
\hline \multirow[t]{2}{*}{ Wool garms } & -11.0 & -11.0 & -10.9 & -11.1 & -48.7 & -14.3 & -64.9 & -48.5 & -25.4 \\
\hline & \multicolumn{9}{|c|}{ (b) Import tax rates faced by exports } \\
\hline Greasy wools & 0 & 0 & -5.84 & 0 & 0 & 0 & -50.68 & -32.92 & -11.98 \\
\hline Scoured wools & -13.98 & -89.36 & -7.54 & 0 & 0 & 0 & -70.32 & -57.65 & -18.17 \\
\hline Carbon wools & 0 & 0 & -33.95 & 0 & -0.01 & 0.02 & -8.81 & -4.34 & -14.68 \\
\hline Worsted tops & -80.06 & -76.73 & -82.54 & -73.93 & -4.49 & -7.92 & -37.83 & -18.03 & -10.88 \\
\hline Noils & -42.07 & -41.52 & -41.29 & -41.05 & 0.00 & -0.02 & -23.84 & -1.23 & -29.29 \\
\hline Wool yarns & -66.82 & -67.07 & -68.03 & -66.87 & 0 & 0 & -59.71 & 0 & -59.34 \\
\hline Wool fabrics & -58.66 & -58.57 & -60.61 & -59.51 & -58.50 & -67.65 & -57.36 & 0 & -60.94 \\
\hline Wool garms & -26.40 & -25.85 & -29.75 & -27.56 & -22.23 & -53.12 & -28.37 & -35.69 & -40.88 \\
\hline
\end{tabular}


Table 6 Partial-equilibrium industry and commodity effects of changes in tariff barriers, 1997-2005 (percentage change)

\begin{tabular}{|c|c|c|c|c|c|c|c|c|c|}
\hline & France & Germ & Italy & UK & USA & Japan & China & Aust & ROW \\
\hline & \multicolumn{9}{|c|}{ (a) Commodity price } \\
\hline Sheep meat & 0.00 & 0.00 & 0.00 & 0.00 & 0.08 & 0.00 & 1.51 & 0.86 & 0.92 \\
\hline Greasy wools & -6.26 & -2.81 & -5.06 & -0.45 & -33.56 & -1.56 & -5.37 & -0.01 & -5.32 \\
\hline Scoured wools & -1.39 & -1.55 & -0.97 & -1.72 & -24.88 & -4.30 & -4.16 & 0.41 & -4.83 \\
\hline Carbon wools & -9.62 & -1.40 & -1.55 & -2.17 & -23.75 & -5.58 & -5.06 & 1.47 & -3.67 \\
\hline Worsted tops & -3.33 & -4.27 & -2.82 & -3.75 & -4.80 & -0.92 & -3.54 & -3.51 & -5.62 \\
\hline Noils & 25.94 & 27.13 & 27.36 & 3.40 & 21.64 & 0.38 & 16.38 & 28.12 & 10.97 \\
\hline Wool yarns & -0.90 & 2.32 & 1.92 & -1.14 & -7.19 & -1.05 & -1.13 & -1.61 & -2.65 \\
\hline Wool fabrics & -0.39 & -0.30 & 0.53 & -0.17 & -2.84 & -0.44 & -5.40 & -0.50 & -5.42 \\
\hline Wool garms & -0.08 & -0.10 & 0.04 & -0.05 & -3.34 & -0.07 & -3.70 & -0.11 & -2.87 \\
\hline Synth textiles & 0.00 & 0.00 & 0.05 & 0.00 & -0.01 & 0.00 & -0.01 & 0.00 & 0.00 \\
\hline \multirow[t]{2}{*}{ Other goods } & 0.00 & 0.00 & 0.00 & 0.00 & 0.00 & 0.00 & 0.00 & 0.00 & 0.00 \\
\hline & \multicolumn{9}{|c|}{ (b) Industry output } \\
\hline Sheep & 0.99 & 0.92 & 0.22 & 0.51 & -0.02 & 0.05 & -2.55 & -2.74 & -1.64 \\
\hline Scoured wools & -0.12 & -16.68 & -9.79 & 11.01 & -53.04 & -6.83 & -19.50 & 8.34 & -3.72 \\
\hline Carbon wools & 117.00 & -54.06 & 66.04 & 45.65 & -75.38 & 7.57 & -23.67 & 33.40 & -25.17 \\
\hline Worsted tops & -4.55 & -2.35 & -11.05 & -25.29 & -31.42 & -19.51 & -24.50 & 4.30 & 8.56 \\
\hline Wool yarns & 18.42 & 3.93 & 29.90 & 23.62 & -77.43 & 1.41 & -32.29 & -1.39 & -37.83 \\
\hline Wool fabrics & 14.15 & 24.93 & 47.57 & 61.39 & -78.70 & 1.24 & -3.87 & -4.18 & -40.90 \\
\hline Wool garms & -10.85 & -9.05 & -10.41 & -2.84 & 1.45 & -1.52 & 4.73 & -3.46 & 5.69 \\
\hline \multirow[t]{2}{*}{ Other indust } & 0.00 & 0.01 & 0.06 & 0.01 & 0.00 & 0.00 & 0.02 & 0.00 & 0.00 \\
\hline & \multicolumn{9}{|c|}{ (c) Imports } \\
\hline Sheep meat & -0.80 & 0.58 & -0.26 & -3.84 & 0.00 & -0.03 & 2.89 & 0.08 & 2.47 \\
\hline Greasy wools & -0.14 & -16.68 & -9.79 & 15.53 & -70.14 & -6.77 & -24.47 & 0 & 28.82 \\
\hline Scoured wools & 17.96 & -2.73 & 65.91 & 23.03 & -74.02 & 0.13 & -76.89 & 0 & 30.26 \\
\hline Carbon wools & 60.65 & 26.79 & 53.43 & 109.80 & -79.98 & -36.05 & -78.01 & 71.78 & 435.37 \\
\hline Worsted tops & 8.69 & 6.96 & 13.35 & -6.52 & -27.64 & -1.74 & -21.22 & -66.01 & 482.89 \\
\hline Noils & 4.21 & -30.41 & 13.54 & 180.40 & -75.05 & 3889.32 & 161.81 & -10.82 & 122.19 \\
\hline Wool yarns & -3.42 & 22.32 & 18.73 & 12.84 & -61.82 & -2.10 & 94.17 & -36.52 & 0.14 \\
\hline Wool fabrics & -10.88 & -9.54 & 9.32 & -3.84 & 589.15 & 0 & 125.58 & 0 & 97.68 \\
\hline Wool garms & 5.20 & 3.95 & 44.52 & 1.36 & 6.78 & 14.20 & 80.50 & 13.05 & 5.66 \\
\hline Synth textiles & 0.04 & 0.01 & 0.26 & 0.02 & -0.06 & 0.01 & -0.01 & 0.01 & 0.00 \\
\hline \multirow[t]{2}{*}{ Other goods } & -0.01 & -0.01 & 0.04 & 0.00 & 0.01 & 0.00 & 0.01 & 0.00 & 0.01 \\
\hline & \multicolumn{9}{|c|}{ (d) Exports } \\
\hline Sheep meat & 7.40 & 11.33 & 11.72 & 12.68 & 8.78 & 12.25 & -16.93 & -6.99 & -5.08 \\
\hline Greasy wools & 0 & -2.98 & -6.71 & -3.95 & 1334.48 & -2.09 & 1.04 & -16.91 & -5.48 \\
\hline Scoured wools & 83.95 & -4.08 & -7.48 & -5.63 & 6192.29 & -0.27 & -8.22 & -7.62 & 29.05 \\
\hline Carbon wools & 196.67 & 48.87 & 114.93 & -0.63 & 5371.49 & -3.19 & 28.29 & 34.42 & 33.37 \\
\hline Worsted tops & -2.02 & 60.44 & -22.03 & -23.39 & 8.36 & -43.89 & 16.98 & 6.20 & 34.80 \\
\hline Noils & -4.10 & 108.29 & -13.88 & -40.34 & -22.28 & 4502.81 & 217.24 & 2.97 & 12.73 \\
\hline Wool yarns & 21.83 & -0.25 & 16.10 & 22.33 & 0 & 0 & 30.49 & 0 & 75.55 \\
\hline Wool fabrics & 35.00 & 40.62 & 77.87 & 77.75 & 139.98 & 134.40 & 389.64 & 0 & 397.44 \\
\hline Wool garms & -13.99 & -21.99 & -17.62 & -3.84 & 67.15 & 8.91 & 21.31 & 3.80 & 19.10 \\
\hline Synth textiles & -0.03 & 0.00 & -0.39 & -0.02 & 0.07 & -0.02 & 0.04 & 0.00 & 0.00 \\
\hline Other goods & 0.01 & 0.02 & 0.07 & 0.01 & 0.01 & 0.01 & 0.10 & 0.01 & 0.02 \\
\hline
\end{tabular}

$\mathbf{a}$ This is the supply (or basic) price in each region.

In most regions the distortionary price effects (Table 6) of the tariff barriers are generally not large; for most wool commodities the tariffs have inflated prices in the order of 5-10\%; the exception is noils where prices are estimated to have been held down by around $20 \%$ in most regions. The large price fluctuations for noils reflect its joint product characteristics in the production of worsted tops; thus, the supply curve for noils is quite steep and any changes in demand will cause large price fluctuations. The largest across-the-board price reductions are experienced in the USA and the ROW, which are the only regions to reduce wool tariffs acrossthe-board. Tariffs on wool fabrics and garments are reduced significantly in all regions, but 
significant price reductions for these products only occur in regions where tariffs are reduced from a high initial rate, i.e., the USA, China and the ROW.

The changes in industry output due to the tariff changes are extreme and divergent reflecting the discriminatory nature of tariffs over this period. For instance, the output of carbonised wools in France doubles (117\%) whereas in the USA it more than halves $(-75 \%)$. Other extreme reductions also occur in the US wool yarns industries (-77\%) and wool fabrics ($79 \%$ ). These results seem consistent with what has been observed in US wool processing from the year 2000 onwards. Large changes are also observed for the carbonised wools industries in Germany (-54\%), Italy (66\%) and the UK (46\%), and for the wool fabrics industries in Italy (48\%), the UK (61\%) and the ROW region $(-41 \%)$. The results also indicate a relocation of wool garments production away from France $(-11 \%)$, Germany $(-9 \%)$ and Italy $(-11 \%)$, largely to China (5\%) and the ROW (6\%).

The changes in industry output do not show any consistent pattern of relocation of production of wool products across regions. This is to be expected as we are implementing observed changes in trade policy for wool products by many countries over the period 19972005. The observed changes are a combination of unilateral tariff reductions and the implementation of multilateral and plurilateral trade agreements. As such, the observed tariff reductions, and thus their effects, would not be expected to show any particular pattern of changes in output and trade across regions. However, the driving forces behind the industry effects of the tariff reductions capture the complex domestic and international interindustry linkages in the wool production system. Given the industry detail in the model, we confine our discussion to explaining two of the largest industry effects observed.

The single largest percentage change in industry output is that observed for the carbonising industries in France: these more than double in size, mainly due to a tripling of exports. Table 5 shows that the huge increase in exports is not due to lower tariff barriers on exports of carbonised wools from France. Instead, it is driven by a large fall in the cost of producing carbonised wools in France $(-10 \%)$ relative to most other regions. This, in turn, is driven by a $10 \%$ fall in the price of imported scoured wools (not reported) used by the carbonising industries; imported scoured wools comprise over $90 \%$ of total scoured wools inputs by the carbonising industries in France. ${ }^{12}$ These imports are sourced from the USA, Japan, China and the ROW, which experience the largest reductions in the price of scoured wools. This example demonstrates that besides the two forces identified earlier as determining the response of a given industry's output to the tariff changes, an industry may expand significantly simply due to cheaper imported wool inputs driven by tariff changes in other regions.

A large effect is also observed for the carbonising industries in the USA, which more than halve in size (-75\%). These industries are almost completely domestically oriented and the large reduction in output is driven exclusively by a $72 \%$ fall in domestic sales of carbonised wools (not reported) ${ }^{13}$ to the domestic yarns industries, who are the only significant users of domesticallyproduced carbonised wools and whose output contracts by $-77 \%$. What causes the wool yarns industries in the USA to contract by $77 \%$ ? Although there is a $26 \%$ fall in the tariff on imported wool yarns in the USA, substitution of imported for domestic wool yarns is not the reason for the large fall in wool yarns output as imports of wool yarns fall by $62 \%$. The only consumers of

\footnotetext{
12 Carbonising industries only use the shortest scoured wools as inputs. Thus, the $10 \%$ fall in the price of imported scoured wool referred to here is the price of the shortest imported scoured wool rather than the price of all imported scoured wool. Scoured wools of medium and greater length are only used as inputs by the worsted top industries.

13 Thus, the 5,371\% rise in exports of carbonised wools from the USA is on an almost zero base and are therefore unimportant.
} 
wool yarns are the wool fabrics industries and these industries contract by $78 \%$ in the USA; thus, demand for both imported and domestic wool yarns falls. As the US wool yarns industries are completely domestically oriented, the huge contraction in the only purchaser of their outputs (the US wool fabrics industries) drives a similarly huge contraction in their own output. Wool fabrics output falls because of a 63\% reduction in tariffs; the single largest fall in wool tariffs in the USA. The changes in the outputs just described are an example of the tightly knit nature of the US wool production system, where changes in downstream industries have strong flow-back effects on upstream industries due to the domestic orientation of US wool industries.

Next we apply the tariff changes to the model and generate a general-equilibrium solution. The industry results (table 7) are very similar to those generated in partial equilibrium. This confirms that the model structure captures enough of the important interindustry and international linkages in the wool production system that drive many of the industry results, even when it is assumed that the wool economy has no effect on primary factor prices. This assumption proves accurate when simulating the tariff changes in general equilibrium; we observe very small changes in factor prices (not reported). Thus, there is little feedback effect through changes in factor prices to the nonwool economy. This can be understood due to the small share of the total economy that the wool economy comprises. With little feedback effect through factor prices, there are only small scale effects on the wool economy from the nonwool economy. Further, wool products are not important inputs to capital creation and thus do not affect the cost of capital and the rate of capital accumulation in long-run general equilibrium when it is assumed that capital is the only factor whose supply can expand. 
Table 7 General-equilibrium industry and commodity effects of changes in tariff barriers, 1997-2005 (percentage change)

\begin{tabular}{|c|c|c|c|c|c|c|c|c|c|}
\hline & France & Germ & Italy & UK & USA & Japan & China & Aust & ROW \\
\hline & \multicolumn{9}{|c|}{ (a) Commodity price ${ }^{\mathbf{a}}$} \\
\hline Sheep meat & 0.12 & 0.17 & 0.19 & 0.10 & 0.06 & 0.07 & 0.31 & 0.49 & 0.47 \\
\hline Greasy wools & -6.65 & -3.37 & -5.63 & -0.75 & -33.63 & -2.21 & -5.90 & -0.83 & -5.74 \\
\hline Scoured wools & -2.23 & -2.33 & -1.96 & -2.19 & -25.06 & -4.91 & -4.69 & -0.19 & -5.27 \\
\hline Carbon wools & -9.80 & -1.74 & -1.75 & -2.33 & -23.85 & -5.80 & -5.34 & 1.21 & -3.88 \\
\hline Worsted tops & -4.01 & -5.01 & -3.58 & -4.20 & -5.56 & -1.64 & -4.25 & -3.85 & -6.15 \\
\hline Noils & 25.14 & 26.37 & 26.56 & 3.11 & 20.66 & 0.36 & 15.59 & 27.70 & 10.69 \\
\hline Wool yarns & -1.05 & 2.13 & 1.85 & -1.24 & -7.23 & -1.09 & -1.31 & -1.59 & -2.74 \\
\hline Wool fabrics & -0.43 & -0.37 & 0.57 & -0.15 & -2.86 & -0.46 & -5.41 & -0.45 & -5.45 \\
\hline Wool garms & -0.04 & -0.06 & 0.16 & 0.01 & -3.35 & -0.05 & -3.62 & -0.04 & -2.84 \\
\hline Synth textiles & 0.05 & 0.05 & 0.13 & 0.05 & 0.01 & 0.04 & 0.07 & 0.06 & 0.04 \\
\hline \multirow[t]{2}{*}{ Other goods } & 0.05 & 0.06 & 0.16 & 0.06 & -0.01 & 0.02 & 0.09 & 0.07 & 0.04 \\
\hline & \multicolumn{9}{|c|}{ (b) Industry output } \\
\hline Sheep & 0.56 & 0.46 & 0.14 & 0.31 & 0.08 & 0.24 & -2.17 & -2.27 & -1.68 \\
\hline Scoured wools & 3.58 & -14.20 & -8.71 & 9.86 & -52.82 & -6.84 & -18.47 & 7.71 & -3.61 \\
\hline Carbon wools & 117.62 & -52.38 & 64.95 & 44.91 & -75.16 & 7.64 & -22.92 & 32.98 & -24.93 \\
\hline Worsted tops & -5.07 & -0.02 & -9.95 & -27.10 & -29.93 & -19.77 & -22.81 & 3.13 & 8.33 \\
\hline Wool yarns & 18.34 & 5.13 & 29.05 & 21.97 & -77.22 & 1.25 & -31.62 & -1.59 & -38.09 \\
\hline Wool fabrics & 14.53 & 26.01 & 46.79 & 61.27 & -78.50 & 1.22 & -3.75 & -4.25 & -40.54 \\
\hline Wool garms & -10.72 & -8.99 & -10.96 & -2.61 & 1.44 & -1.56 & 4.40 & -3.53 & 5.85 \\
\hline \multirow[t]{2}{*}{ Other indust } & 0.00 & 0.00 & 0.03 & 0.00 & -0.02 & 0.00 & 0.00 & -0.02 & -0.01 \\
\hline & \multicolumn{9}{|c|}{ (c) Imports } \\
\hline Sheep meat & -4.36 & -3.34 & -0.33 & -4.11 & -7.17 & -1.63 & -1.05 & 2.94 & 3.93 \\
\hline Greasy wools & 3.57 & -14.19 & -8.71 & 14.23 & -69.58 & -6.78 & -23.56 & 0 & 29.61 \\
\hline Scoured wools & 17.44 & -1.15 & 64.82 & 22.68 & -73.54 & -0.31 & -76.23 & 0 & 30.00 \\
\hline Carbon wools & 60.49 & 28.02 & 52.50 & 109.45 & -79.83 & -36.09 & -78.22 & 72.44 & 433.55 \\
\hline Worsted tops & 8.24 & 7.60 & 12.65 & -7.34 & -28.06 & -2.76 & -24.24 & -67.57 & 478.69 \\
\hline Noils & 4.86 & -30.33 & 13.00 & 176.20 & -74.88 & 3886.73 & 148.57 & -10.79 & 120.95 \\
\hline Wool yarns & -3.12 & 22.50 & 18.64 & 13.04 & -61.59 & -1.65 & 93.26 & -36.06 & 0.83 \\
\hline Wool fabrics & -10.92 & -9.68 & 9.19 & -3.65 & 587.97 & 0 & 124.65 & 0 & 97.66 \\
\hline Wool garms & 5.36 & 3.99 & 58.57 & 1.40 & 6.87 & 14.68 & 86.50 & 13.30 & 5.94 \\
\hline Synth textiles & 0.06 & 0.03 & 0.71 & 0.05 & -0.31 & -0.07 & 0.18 & 0.08 & -0.03 \\
\hline \multirow[t]{2}{*}{ Other goods } & 0.00 & 0.01 & 0.28 & 0.02 & -0.14 & -0.04 & 0.10 & 0.02 & 0.00 \\
\hline & \multicolumn{9}{|c|}{ (d) Exports } \\
\hline Sheep meat & 3.45 & 4.80 & 4.02 & 4.59 & 5.94 & 1.78 & 0.67 & 0.34 & -5.02 \\
\hline Greasy wools & 0.00 & -4.41 & -7.80 & -4.33 & 1301.65 & -2.91 & 0.64 & -15.72 & -5.54 \\
\hline Scoured wools & 82.32 & 1.20 & -4.45 & -5.88 & 6126.63 & 1.22 & -8.10 & -8.09 & 29.40 \\
\hline Carbon wools & 197.33 & 54.32 & 114.65 & -0.41 & 5281.96 & -3.07 & 30.70 & 33.99 & 34.28 \\
\hline Worsted tops & -2.57 & 62.23 & -21.51 & -24.67 & 10.92 & -44.30 & 20.86 & 4.96 & 34.53 \\
\hline Noils & -4.66 & 115.50 & -11.94 & -42.50 & -20.56 & 4017.97 & 227.69 & 1.86 & 12.51 \\
\hline Wool yarns & 21.61 & 0.67 & 15.71 & 20.64 & 0 & 0 & 32.00 & 0 & 74.58 \\
\hline Wool fabrics & 35.41 & 41.80 & 77.02 & 77.54 & 142.42 & 135.44 & 390.83 & 0 & 399.56 \\
\hline Wool garms & -13.20 & -21.60 & -17.98 & -1.08 & 69.28 & 11.41 & 21.55 & 6.28 & 19.90 \\
\hline Synth textiles & -0.03 & -0.05 & -0.66 & -0.07 & 0.28 & 0.06 & -0.25 & -0.06 & -0.01 \\
\hline Other goods & -0.01 & -0.02 & -0.18 & -0.03 & 0.12 & 0.02 & -0.04 & -0.07 & -0.01 \\
\hline
\end{tabular}

$\mathbf{a}$ This is the supply (or basic) price in each region.

\subsection{Macroeconomic effects}

Here we compare the macroeconomic effects of simulating the tariff changes in partial and general equilibrium (table 8). In partial equilibrium, there is no change in relative factor prices. As such, the change in primary factors is purely demand driven. In general equilibrium, relative factor prices are endogenous. Thus, a key to explaining the general-equilibrium macroeconomic effects is the change in relative factor prices. This will be driven by two potential initial effects of the tariff reductions. First, the prices of imported wool products fall; wool industries and consumers substitute imported for domestic wool products and, ceteris paribus, domestic wool 
industries contract. Thus, the demand for domestic nonwool inputs falls and this causes domestic nonwool industries to also contract. Demands for primary factors fall; this benefits the fixed factors, i.e., land and labour, and disadvantages the variable factor, i.e., capital. The relative price of capital increases causing industries to substitute land and labour for capital. The size of this initial effect is indicated by the percentage change in the average indirect tax rate due to the tariff reductions weighted by the share of the indirect taxes in GDP (table 8, row 1); thus, the initial effect is smallest in the European regions and Japan and largest in the USA, China, Australia and the ROW. The small size of these changes indicates that the economywide effect of cheaper wool products should not be large; an intuitive result.

Table 8 Macroeconomic effects of changes in wool tariff barriers, 1997-2005 (percentage change)

\begin{tabular}{|c|c|c|c|c|c|c|c|c|c|c|}
\hline & France & Germ & Italy & UK & USA & Japan & China & Aust & ROW & World \\
\hline 1. Ind tax rate $\mathbf{a}^{\mathbf{a}}$ & -0.0013 & -0.0019 & -0.0007 & -0.0018 & -0.0279 & -0.0013 & -0.0451 & -0.0144 & -0.0204 & \\
\hline 2. Export tariff $\mathbf{b}$ & -0.1818 & -0.6521 & -2.4015 & -0.1409 & -0.0158 & -0.0299 & -0.5856 & -0.1229 & -0.4975 & \\
\hline & \multicolumn{10}{|c|}{ Partial equilibrium } \\
\hline 3. Real GDP & 0.0035 & 0.0068 & 0.1145 & 0.0155 & 0.0006 & -0.0030 & 0.0809 & -0.0022 & 0.0142 & 0.0125 \\
\hline 4. Value added & 0.0005 & 0.0029 & 0.1103 & 0.0131 & -0.0177 & -0.0045 & 0.0255 & -0.0047 & 0.0020 & 0.0003 \\
\hline 5. Ind tax base ${ }^{\mathbf{c}}$ & 0.0227 & 0.0411 & 0.1582 & 0.0478 & 0.5426 & 0.0060 & 0.3348 & 0.0215 & 0.1267 & 0.1372 \\
\hline 6. Real income & 0.0108 & 0.0162 & 0.1103 & 0.0238 & 0.0352 & 0.0018 & 0.1206 & 0.0236 & 0.0326 & \\
\hline \multirow[t]{2}{*}{ a. US\$ million } & 90 & 173 & 787 & 229 & 2,227 & 59 & 903 & 73 & 2,440 & \\
\hline & \multicolumn{10}{|c|}{ General equilibrium } \\
\hline 7. Real GDP & 0.0007 & -0.0003 & 0.0856 & 0.0052 & -0.0155 & -0.0008 & 0.0577 & -0.0219 & -0.0034 & -0.0006 \\
\hline 8. Value added & -0.0028 & -0.0054 & 0.0753 & 0.0024 & -0.0332 & -0.0020 & -0.0024 & -0.0254 & -0.0155 & -0.0132 \\
\hline 9. Capital stock & -0.0056 & -0.0122 & 0.1399 & 0.0066 & -0.0886 & -0.0051 & -0.0063 & -0.0565 & -0.0346 & -0.0316 \\
\hline 10. Ind tax base ${ }^{\mathbf{c}}$ & 0.0229 & 0.0438 & 0.1925 & 0.0436 & 0.5074 & 0.0063 & 0.3335 & 0.0092 & 0.1083 & 0.1281 \\
\hline 11. Real income & 0.0038 & 0.0038 & 0.1281 & 0.0149 & -0.0165 & 0.0013 & 0.0859 & -0.0287 & -0.0057 & \\
\hline a. US\$ million & 32 & 40 & 915 & 143 & $-1,043$ & 44 & 643 & -89 & -427 & \\
\hline
\end{tabular}

$\mathbf{a}$ Indirect tax rate weighted by share of indirect taxes in GDP. $\mathbf{b}$ Tariff rate faced by exports weighted by share of exports in GDP. ${ }^{\mathbf{c}}$ This is qnit in equation (2); see text for explanation.

Second, the demand for exports of wool products rises. Substitution of cheaper imported wool products for domestic wool products favours regions from which imported wool products are sourced. Increased demand for exports of wool products causes domestic wool industries in exporting regions to expand. The demand for domestic nonwool inputs rises and causes domestic nonwool industries to expand. Ceteris paribus, expanding wool and nonwool industries increases overall demand for primary factors. This benefits the variable factor and disadvantages the fixed factors; the relative price of capital falls, leading industries to substitute capital for land and labour. A measure of the size of this effect is the percentage change in the average tariff barrier faced by exports weighted by the share of exports in GDP (table 8, row 2).

This measure indicates that, ceteris paribus, Italy is expected to experience far and away the strongest increase in export demand and this is because of the large share (5\%) that wool textiles and garments comprise in total exports; wool textiles and garments experience the largest reductions in global tariff barriers over 1997-2005. Germany, China and the ROW are expected to experience less significant increases in export demand as the export shares for wool textiles and garments are somewhat smaller than Italy's - 0.8\%, $2.1 \%$ and $0.5 \%$ - but still much larger than in other regions. The pattern of exports also explain why Australia is expected to experience only a small increase in exports; its exports are heavily skewed towards raw wool and these products experienced the smallest reductions in global tariff barriers over the period.

The relative sizes of the two initial effects will largely determine the size of the (partialand general-equilibrium) effects on economic activity in a given region (real GDP). The real 
GDP effects are more favourable, for most regions, in the partial-equilibrium solution. The largest positive effects are observed in Italy $(0.115 \%$ and $0.086 \%)$ and China $(0.081 \%$ and $0.058 \%$ ); both of which experience large reductions in the tariff barriers faced by their exports (row 2). For Germany, USA and ROW, the partial-equilibrium solution predicts real GDP increases whereas the general-equilibrium solution predicts real GDP decreases. For Australia, the two solutions suggest lower real GDP but differ by a factor of $10(-0.002$ and $-0.022 \%)$;

The qualitative and quantitative differences in net output from the two model solutions can be explained by a formal definition of real GDP. We can define the percentage change in real GDP $(q g d p)$ from the income side as a function of the change in the use of resources in the economy and/or the change in the efficiency with which resources are used in the economy, i.e.,

$$
q g d p=\text { SVAqva }+ \text { SNITqnit }
$$

where qva and qnit are the percentage changes in real value added and the quantity base upon which net (of subsidies) indirect taxes are levied, and $S V A$ and $S N I T$ are the shares of value added and net indirect taxes in GDP.

qva measures the change in the use of resources; all primary factors are variable in the partial-equilibrium solution and only capital is variable in the general-equilibrium solution. qnit measures the change in the efficiency with which resources are used in the economy. This can happen via a change in tax rates (e.g., tariffs) and/or a change in the tax bases. Tax bases can change via price or quantity movements. The model distinguishes many indirect taxes (see Verikios 2006a). Where the composition of sectoral outputs and sales do not change, qnit and $q v a$ in (20) will move together, as qnit is the weighted sum of sales and qva is the weighted sum of (net) industry outputs. But the tariff changes will induce a change in each economy's production and sales structure; if the changes favour industries that are relatively highly taxed, qnit will be positive, if the changes favour industries that are relatively lightly taxed (or subsidised), qnit will be negative.

The compositional changes cause $q v a$ and qnit to diverge in most regions; the divergences are much larger in the general-equilibrium solution. However, the allocative efficiency effects are very similar in the two solutions. This reflects the similarity of industry effects in the two solutions that was noted earlier. Thus, the differences in real GDP between the two solutions are due mainly to the differences in $q v a$.

In partial equilibrium, qva expands in all regions except USA, Japan and Australia. In the USA and Australia, the contraction in $q v a$, and therefore $q g d p$, is underestimated by the partialequilibrium solution. In general equilibrium, the tariff changes cause $q v a$ to fall in most regions due to a fall in the use of capital. Here, the changes in qva explain why qgdp expands in Italy and the UK - both experience an increase in the use of capital - and why $q g d p$ falls in most other regions - where capital usage falls. For China, qva falls but $q g d p$ still increases due to the large increase in qnit.

The welfare effects of the tariff changes, as measured by real household income, are largely consistent with the real GDP effects in the two solutions; welfare is predicted to be higher in all regions in the partial-equilibrium solution, but lower in the USA, Australia and ROW in general equilibrium. ${ }^{14}$ With welfare effects closely following the GDP effects, the overestimation of GDP gains by the partial analysis is reflected in the (overestimated) welfare effects. The general analysis predicts that Italy $(0.128 \%)$, China $(0.086 \%)$ and the UK $(0.015 \%)$ are the largest

\footnotetext{
14 Real household income is a metric of the change in the Hicksian equivalent variation.
} 
gainers from the movement in wool tariffs between 1997 and 2005; these gains are worth approximately \$915, \$643 and \$143 million annually in 1997 US dollars. ${ }^{15}$

Our estimates of the effects of wool tariffs indicate that, in general, the economywide effects are small. But for some regions the absolute size of the real income effects are comparable to recent estimates of the effects of an OECD-based trade liberalisation agreement including agriculture, manufacturing and services (Francois et al. 2005). ${ }^{16}$ We estimate a real income effect of $0.086 \%$ for China. Francois et al. (2005) estimate a real income loss in the order of $0.1 \%$ for China (see table 8 , p.374). Francois et al. (2005) also estimate a gain of $0.4 \%$ for the 'Rest of EU 15' (a region including Italy). Our estimates indicate that wool tariffs have around one-third (0.128\%) of the effect on real income for Italy of an OECD-based trade round.

\section{Conclusion}

This work makes a contribution to modelling the world wool market by developing a model that extends previous work into new areas. The model is a hybrid by combining the partialequilibrium commodity-specific approach with the computable-general-equilibrium approach. By doing so, the model contains a detailed depiction of the multistage wool production system within a broader economywide framework.

We explore the model's utility by applying it to estimate the direct (partial equilibrium) and indirect (general equilibrium) effects of wool tariff barriers over the period 1997-2005, which are of interest to trade negotiators, policy makers and producers. Numerical assessments of the effects, global or otherwise, of wool tariff barriers are nonexistent. The contribution of the approach is evaluated by estimating the direct and indirect effects separately via different model solutions.

The results indicate that the nature of recent wool tariffs severely distort the size of wool industries in different regions. The changes in the output of wool commodities are extreme reflecting the discriminatory nature of the tariffs. Examples include a doubling of carbonised wools output in France whereas in the USA it more than halves. Other extreme reductions also occur in US production of wool yarns $(-77 \%)$ and wool fabrics $(-79 \%)$. The results also indicate a relocation of wool garments production away from France, Germany and Italy, largely to China and the ROW region. The partial- and general-equilibrium solutions give similar estimates of industry effects, indicating that the model structure captures enough of the important interindustry and international linkages in the wool production system that drive the industry results.

In contrast, GDP and welfare effects differ markedly between the two solutions. This is mainly due to the estimated effects on the use of resources in the economy; estimates of the efficiency of resource use are very similar across the two solutions. Partial-equilibrium analysis suggests higher output for almost all regions due to the tariff changes; general-equilibrium analysis suggests higher output for about half the regions due to the tariff changes. The differences reflect the absence of resource constraints in the partial-equilibrium solution. Our results suggest that modelling trade distortions in the absence of resource constraints can lead to unreliable welfare estimates.

\footnotetext{
15 It would be appropriate to investigate the sensitivity of the model results with respect to key parameters so as to assess the robustness of the results. However, our estimates are meant to be illustrative of the differences in partial- and general-equilibrium analysis As such, sensitivity analysis is outside the scope the present paper.

16 The authors estimate the effects of a global trade round and an OECD trade round; they consider the OECD trade round as realistic. The OECD round involves no actual liberalisation by developing countries and a $50 \%$ reduction in all trade protection measures for agriculture, manufactures and services by OECD countries (see pp. 366-7).
} 
APPENDIX Mapping from model industries to commodities Industries Commodities

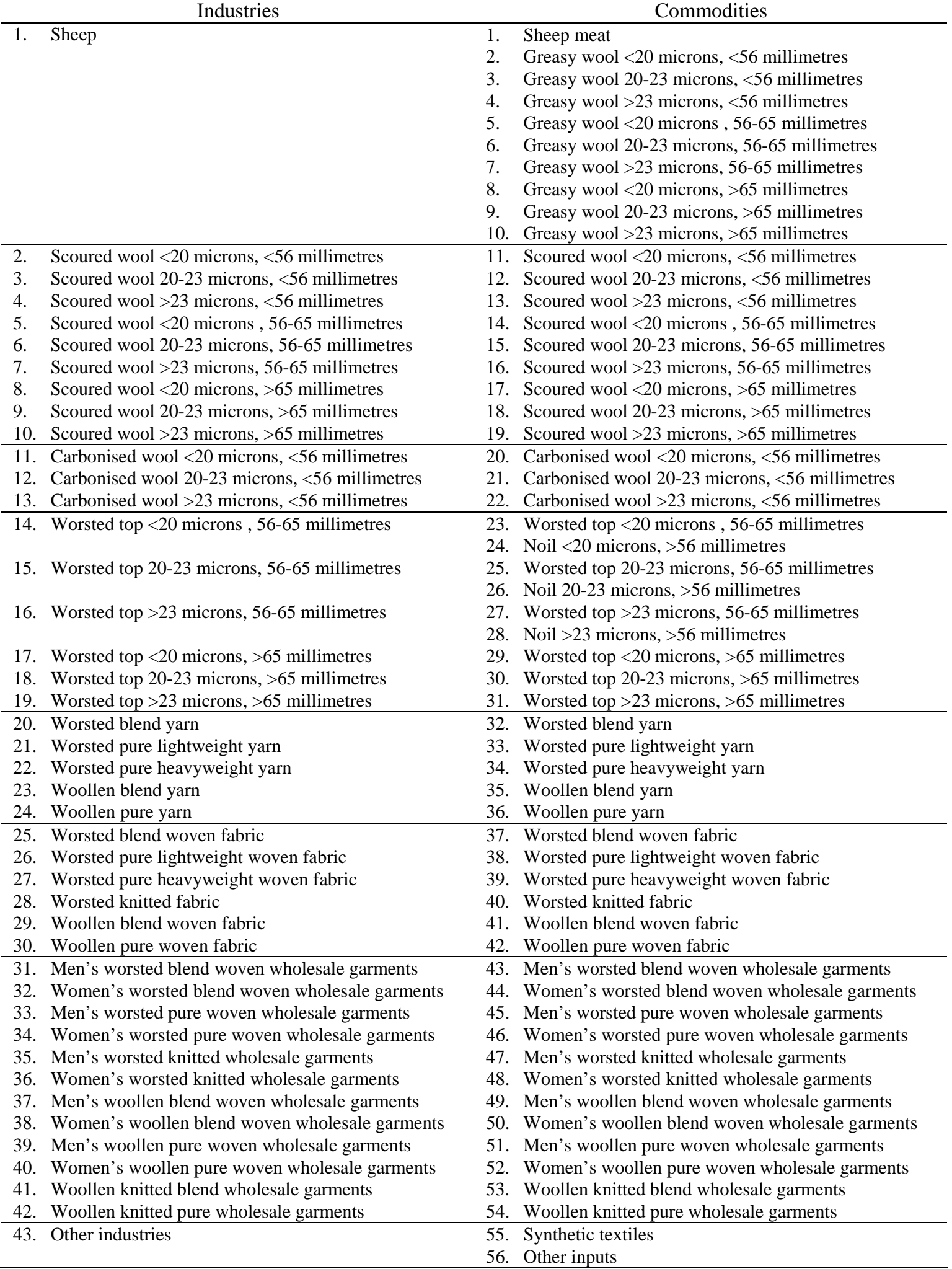




\section{References}

AWIL (Australian Wool Innovation Limited) (2005), Wool Marketing and Risk Management Scoping Study (EC740), AWIL, Sydney.

AWIL (2006), Wool Facts, AWIL, Sydney.

Beare, S. and Meshios, H. (1990), 'Substitution between wools of different fibre diameter', Australian Journal of Agricultural Economics, vol. 34, no. 1, pp. 56-66.

CIE (Centre for International Economics) (2002), Prospects for Further Wool Processing in Australia, CIE, Canberra.

Clements, K.W., Lan, Y. and Zhao, X. (2006), The Demand for Vice: Inter-commodity Interactions with Uncertainty, Discussion Paper 06.30, Economics Program, The University of Western Australia. (available at www.ecom.uwa.edu.au/research/discussion_papersworking_documents/economics/2006)

Clements, K.W., Selvanathan, S. and Selvanathan, E.A. (1995), 'The economic theory of the consumer', in Selvanathan, E.A. and Clements, K.W. (eds), Recent Developments in Applied Demand Analysis: Alcohol, Advertising and Global Consumption, Spinger Verlag, Berlin, pp. 1-72.

Connolly, G.P. (1992), World Wool Trade Model, ABARE Research Report 92.12, AGPS, Canberra.

DAWA (Department of Agriculture Western Australia) (2003), Wool Desk, South Perth, Western Australia.

Dimaranan, B.V. and McDougall, R.A. (2002), Global Trade, Assistance, and Production: The GTAP 5 Data Base, Center for Global Trade Analysis, Purdue University West Lafayette.

Dixon, P.B., Parmenter, B.R., Powell, A.A. and Wilcoxen, P.J. (1992), Notes and Problems in Applied General Equilibrium Economics, North-Holland, Amsterdam.

Francois, J., van Meijl, H. and van Tongeren, F. (2005), 'Trade liberalization in the Doha Development Round', Economic Policy, April, pp. 350-91.

Guvenen, O., Labys, W. and Lesourd, J.B. (eds.) (1991), International Commodity Market Models: Advances in Methodology and Applications, Chapman and Hall, London.

Harrison, W.J. and Pearson, K.R. (1996), 'Computing solutions for large general equilibrium models using GEMPACK’, Computational Economics, vol. 9, pp. 83-127.

Jha, R., Murhty, M.N., Paul, S. and Rao, B. (1993), 'An analysis of technological change, factor substitution and economies of scale in manufacturing industries in India', Applied Economics, vol. 25, pp. 1337-43.

Layman, B.D. (1999), 'A structural model of the world wool market', Presented at the $43^{\text {rd }}$ Australian Agricultural and Resource Economics Society Conference, 20-22 January, 1999, Christchurch, New Zealand.

Mullen, J.D., Alston, J.M. and Wohlgenant, M.K. (1989), 'The impact of farm and processing research on the Australian wool industry', Australian Journal of Agricultural Economics, vol. 33, no. 1, pp. 32-47.

O'Donnell, C.J. and Woodland, A.D. (1995), 'Estimation of Australian wool and lamb production technologies under uncertainty: an error-components approach', American Journal of Agricultural Economics, vol. 77, no. 3, pp. 552-65.

Ramcharran, H. (2001), 'Estimating productivity and returns to scale in the US textile industry', Empirical Economics, vol. 26, no. 3, pp. 515-24.

Read, R. (2004), 'China's wool non-tariff barriers and the WTO accession', AWIL Trade Program Briefing Paper No. 2., AWIL.

Salhofer, K. (2000), Elasticities of Substitution and Factor Supply Elasticities in European Agriculture: A Review of Past Studies, Diskussionspapier Nr.83-W-2000, Department of Economics, Politics and Law, University of Agricultural Sciences, Vienna, September.

Swan Consultants (1992), Fibre Substitution in the United Kingdom Worsted Spinning Sector, Canberra.

TWC (The Woolmark Company) (2002), Wool Fact File 2001/2002, TWC, Melbourne, Australia.

TWC (2003), Unpublished data, TWC, Melbourne, Australia.

TWC (2004), Wool Fact File 2003/2004, TWC, Melbourne, Australia.

TWC (2006), Unpublished data, TWC, Melbourne, Australia.

Theil, H. (1980), The System-Wide Approach to Microeconomics, The University of Chicago Press, Chicago. 
Trela, I. and Whalley, J. (1990), 'Global effects of developed country trade restrictions on textiles and apparel’, The Economic Journal, vol. 100, no. 403, pp. 1190-1205.

Tulpule, V., Johnston, B. and Foster, M. (1992), TEXTABARE: A Model for Assessing the Benefits of Wool Textile Research, ABARE Research Report 92.6, AGPS, Canberra.

van Rooyen, B. (2006), 'Wool and Australia's FTA with China', APEC Economies Newsletter, vol. 9, no. 3.

Verikios, G. (2004), A Model of the World Wool Market, Discussion Paper 04.24, Economics Program, The University of Western Australia. (available at www.ecom.uwa.edu.au/research/discussion_papersworking_documents/economics/2006)

Verikios, G. (2006a). Understanding the World Wool Market: Trade, Productivity and Grower Incomes, Part III, A Model of the World Wool Market. Discussion Paper 06.21, Economics Program, The University of Western Australia. (available at www.ecom.uwa.edu.au/research/discussion_papersworking_documents/economics/2006)

Verikios, G. (2006b). Understanding the World Wool Market: Trade, Productivity and Grower Incomes, Part IV, Model Data and Parameters. Discussion Paper 06.22, Economics Program, The University of Western Australia. (available www.ecom.uwa.edu.au/research/discussion_papersworking_documents/economics/2006)

Whalley, J. (1975), 'How reliable is partial equilibrium analysis?', The Review of Economics and Statistics, vol. 57, no. 3, pp. 299-310.

Whipple, G.D. and Menkhaus, D.J. (1989), 'Supply response in the U.S. sheep industry', American Journal of Agricultural Economics, vol. 71, no. 1, pp. 126-35. 